\title{
Becoming a (Re)Searcher: Negotiating Literacies and Uncertainty
}

\author{
DARCY COURTLAND \\ University of Alberta
}

\begin{abstract}
In this paper I explore my evolving understandings of literacy and ways of knowing. Using autobiographical narrative inquiry (Clandinin \& Connelly, 2000), the first section of my paper delves into the ways I have previously negotiated concepts of literacy as an educator and novice researcher. In the second section of my paper, I turn towards Indigenous scholarship (Antone, 2003; Cardinal, 2010; Young, 2005) as I embrace my conception of literacy as "life lived" in conjunction with Freire's (1985) concept of dwelling in uncertainty. By engaging narratively with my own literacy and learning experiences during the first year of my doctoral program, I negotiate uncertainty through three threads of learning: slowing down, being open to vulnerability, and walking humbly in good ways.
\end{abstract}

\section{Becoming a (Re)Searcher: Negotiating Literacies and Uncertainty}

[Literacy education] suggests that we teachers should be constantly asking questions of ourselves and of our students, to create a spirit in which we are certain by not being certain of our certainties.

- Paulo Freire

Paulo Freire (1985) posits that the pedagogy of teachers can never be neutral, "education must be either liberating or domesticating" (p. 17). As such, inquiring into my positionality as a non-Indigenous literacy educator and emerging scholar is both vital and timely. Acknowledging my understanding of literacy, and the influences that have shaped them, is a commitment to ensure my contributions to education and educational research are not among the domesticating voices within dominant narratives. Yet, merely examining hegemonic values embedded in research and practice is not enough on its own to disrupt colonial narratives that are so deeply historically embedded within Eurocentric scholarship (Boler, 2004). Freire (1985) offers, "the only way to ... unveil reality, is to create a counter-ideology to help us break the dominant ideology" (p. 18). The counterideology I explore in this paper embraces story and uncertainty as a means to critically examine my own evolving understandings of literacy.

I use autobiographical narrative inquiry as "a way of understanding experiences" (Clandinin \& Connelly, 2000, p. 20) and in this first section address two purposes. First, I delve into the various ways I have come to think with (Clandinin \& Connelly, 2000) literacy overtime, as a student, a teacher, and now as an emerging researcher. Second, I unveil some of the ways I negotiated uncertainty in my first year of doctoral studies while operating within dominant narratives of literacy and learning. I begin by showcasing the internal conversations of my evolving understandings of literacy, which were encapsulated in narratives and personal writing. This helps me to navigate the ways I have previously thought about literacy as I begin to articulate my current conception of "literacy as life lived". Within this created space of a counter-ideology, I am afforded possibilities to 
playfully and intentionally wonder how shifting narratives of literacy could broaden understandings of competency and lead to less curricular and pedagogical violence (Freire, 1985; Seidel, 2014).

In the second section of my paper, I embrace my conception of literacy as life lived in conjunction with Freire's (1985) concept of dwelling in uncertainty. Freire (1985) posits that this inward turn is necessary for understanding how to teach Language Arts, which "is accomplished by reflecting critically on our concrete experiences, to consider the raison d'etre of the facts we reflect on" (p. 18). I explore three resonant threads of slowing down, being open to vulnerability, and trying to walk in good ways. These threads depict my own experiences of the ways I am becoming more comfortable "not being certain of [my] certainties" (Freire, 1985, p. 17). To honour the essence of this unfolding narrative inquiry, I conclude not with definitive answers or recommendations, but instead invite the reader to think with my stories and be open to imagining their own possibilities of literacy as life lived.

\section{Part One}

Story speaks to my heart, to who I am as a woman, a teacher, and a learner. I have come to see that story can also speak to who I am as a researcher. I note that I still rush, I still overanalyze, and I still feel ashamed when I struggle. But, I also see that my pursuit to slow down and be present has echoed throughout this course since the very beginning. I recognize how many Indigenous teachings are calling me to see this clearer. "Couture $(1991,60)$ calls this "living in the perennial now" being concerned only with making the most of the moment at hand. After all, in a rapidly changing and unpredictable world, the moment is the only sure thing; all else is without guarantee." (Friesen \& Snow, 2016, p. 23).

- Honouring Indigenous, Personal, and Relational Knowledge in Literacy Learning (graduate course), Final Reflection; December 2018

Through writing and rewriting, storying and restorying, searching and researching, I begin to see and appreciate the intricacy of the stories that inform who I am as a woman, a learner, and as a researcher. This has not been the easily accessible process I silently hoped for. I am still learning about intentionality; I am still learning to slow down.

Framing the Inquiry through Autobiographical Narrative Inquiry

My own stories have come from a place not just of telling, but of braiding together memories, thoughts, feelings, and senses over time. Weaving in and out of places and across milieus. These stories have been intimate, those shared by me and by others. They have required me to slow down and pull up a seat. As I write this now... I can feel the stories still heavy in the room, because once you have invited them in and demonstrated you're listening, they cling to you.

- Honouring Indigenous, Personal, and Relational Knowledge in Literacy Learning (graduate course), Final Reflection; December 2018

In my first semester of my doctoral program I was introduced to autobiographical narrative inquiry by Dr. Trudy Cardinal during the Honouring Indigenous, Personal, and Relational Knowledge in Literacy Learning course. I immediately felt something stir within me, it felt like home. Jean Clandinin and Michael Connelly (2000) introduced narrative inquiry as a way to think with stories, differing from other narrative 
methodologies which were intended to think about stories. It is offered as a study of experience, but, more centrally, it is a way of thinking with and understanding experiences. This view of narrative inquiry as both a methodology (with story as the unit of analysis) and a phenomenon (stories as a way of life), encourages and requires narrative researchers to first think about stories as a way of understanding the world. Before stories can be used to study the world, researchers must acknowledge life is "filled with narrative fragments, enacted in storied moments of time and space, and reflected upon and understood in terms of narrative unities and discontinuities" (Clandinin \& Connelly, 2000, p. 17).

As an autobiographical narrative inquirer, I am called to be wide-awake (Greene, 1995 ) to the fragments of new and unfolding ideas, connections, and experiences that guide me in becoming a researcher. I give voice to my own thoughts and experiences by sharing my collection of journalled experiences, voice recordings, visual representations, and course assignments. These field texts (data) are embedded in italics throughout this research text along with quotes and lyrics that have called me to think. I invite you, the reader, in to think with me as I braid my stories through dimensions of time, place, and sociality (Clandinin \& Connelly, 2000). As a novice researcher, I am working to understand and honour narrative inquiry as a slow process that involves "working toward intimacy of relationship" (Clandinin \& Connelly, 2000, p. 78), often with myself. These concepts enable me to see the relational nature of narrative inquiry through relationships between the stories I have lived by across time, weaving in and out of the past, present, and future, in relation to places, and in relation to a multiplicity of other emotions, people, and narratives. Further, my commitment to honouring story and experience holistically as a non-linear process is reflected in my understanding that "stories to live by are fluid, always shaped by the embodied, temporal notion of becoming, and link knowledge, context, and identity" (Caine, Estefan \& Clandinin, 2013, p. 581). The reflexivity and inquiry into becoming "affords the 'space' to decolonize western research methodologies" (Martin, 2003, p. 14).

Appreciative of this space, I humbly and consciously weave Indigenous teachings, which encompass valued knowledge derived from traditional teachings, empirical observation, and revelation (Brant Castellano, 2000), throughout my writing. Indigenous teachings are distinct in their own concepts of epistemology and validity and are holistic, pertaining to body, mind, emotion and spirit (Battiste, 2008). It is important to acknowledge the sources of these teachings and I do so with gratitude. I am indebted to my gracious mentors, and to the Land I work and play on, Alberta Treaties 6 and 7, for the nourishment and sustenance they have given me. I acknowledge and pray that the teachings I have been gifted continue to guide and shape my learning journey, as they support me in intimately considering literacy as a four-part person: heart, mind, body, and spirit.

\section{Negotiating “Literacy”}

I was born into a world of literature and fantasy. Since before I can remember I was immersed in books and stories. Every occasion called for a new book that found a way to my heart. Some told stories that could make me laugh or cry, while others illustrated pictures that captivated me time and time again. To me, books were magical.

- Literacy Autobiography; June 2010 
Having grown up in diverse communities in Calgary, Alberta, I intimately explored my positionality within non-white spaces. I honoured and valued friends who were fortunate to be literate in multiple languages, who were rooted through a sense of intimately knowing their homeplace and cultural identities. I enthusiastically took part in festivals and ceremonies when invited and listened with great interest when anyone was willing to share who they were with me. All the while, I grappled with my own cultural identity as a thirteenth and fifth generation Irish-Canadian on either side of my family. Coming from a middle-class, well-educated settler family, I've benefited from the privileges that come with this positionality, both historically and in my own lifetime. Yet, the spaces I found myself in enabled me to recognize how limited I was in my ways of knowing and being. I lacked the ability to read the world (Freire, 1985) in many diverse ways. In viewing literacy as a broad term referring to ways of making meaning, comfortability, and competency, I question how truly literate I was.

- Personal Journal, March 2020

The theme of the $16^{\text {th }}$ annual Language and Literacy Researchers of Canada (LLRC) pre-conference, Unsettling Research and Practices, was well suited for many of the conversations I was already engaging in. As a novice researcher in the fields of language and literacy and Indigenous education, a question posed by the LLRC preconference co-chairs called me to consider how tensions between multiple ways of knowing and meaning-making could be negotiated. As a new doctoral student and nonIndigenous woman, inquiring into my own responsibilities as a Treaty person, I was becoming familiar navigating such tensions. One tension that continued to tug at me was my inability to find a definition of literacy that truly resonated within me. In attempt to define literacy for myself, I first consider the two excerpts from my own personal writing, shared at the beginning of this section.

The first excerpt comes from a literary autobiography I wrote at the beginning of a longitudinal study (See Courtland, Leslie, \& Courtland, 2011). This study explored my journey into teaching and the emergence of my professional identity as a teacher of literacy. It was unique in that it spanned my university and pre-service experiences and continued throughout my first years of teaching. Further, it was special because it was cocomposed by my grandmother, her doctoral student, and me as a researcher/participant. As I considered this snapshot in time, while also analyzing my entire Literacy Autobiography, I noted the many ways I had been thinking of literacy as written text and oral storytelling. I drew confidently on my love of stories and explored intergenerational narratives that fuelled my appreciation for the written and spoken word. I fondly remember writing the Literacy Autobiography on an airplane to Orlando, Florida. I carefully chose each word, hoping to capture the magic I felt thinking of "literacy". I was assured I knew what it meant; after all, I grew up with it! However, the second excerpt, written nearly ten years later, sheds light on my uncertainty of what it means to be literate and my questioning of what constitutes literacy.

Attending to the second excerpt, it is interesting for me to reread a more recent negotiation of literacy and how I am making sense of my own literacies and lack thereof. I am pulled back to a memory of writing this journal entry at my dining room table, in an attempt to make sense of how dominant narratives of whiteness prevail in our school systems when, conversely, I can recognize how limited my ability to make sense of the 
world is in comparison to many who may be considered marginalized. I have started to awake to the limitations of my ability to communicate and make sense of the world due to my own whiteness. Additionally, I recognize the tensions I have between heart and home. Although I was born here on the Land referred to as Canada, there is a lack of sense of belonging because my cultural roots are not tied to this Land; they are tied to a Land I have never touched or seen. I begin to dance with how this impacts my ability to be literate in understandings of culture and home. Pointing to how I view more culturally literate others as being rooted, I am left to question if I see myself as unrooted? Across my writing within my doctoral program, I note themes of disconnection, up-rootedness, and insecurity were very present alongside dialogue of situating myself. This notion calls me to journey further within myself, to ground myself in my own understandings and experiences to better negotiate how I have come to understand literacy.

\section{When One Size Does Not Fit All}

Like a story, classrooms are composed of a complex flow of personal and social ideas and ideals, triumphs and tribulations. The story of any classroom can be full of intense emotion as each child, set as the protagonist, faces their own challenges and learns to navigate their educational journey. The role of teacher in contemporary classroom narratives is changing, from sole authority to that of shared authorship with their students.

- Introduction, Unpublished Master's Project, 2017

In the time that has passed between my two attempts to define literacy, I finished my education degree and have since been an elementary (K-6) teacher in southern Alberta classrooms. With each new school year, I have met students who remind me of my brothers; exceptional learners who struggled to excel in one-size-fits-all systems of education. Although these learners-bright and full of personality-could tell you so incredibly much about infinite matters, they are often looked upon through lenses of literacy deficit. As I find the words to describe these children in writing, faces of students flood my memories, along with the familiar ache of hoping each one would continue to see the light within themselves. This ache comes from my frustration as an educator, a sister, and one who has seen the long-term impacts of trying to make children "fit" school. The ache is only heightened when I reflect on my own experiences navigating dominant narratives of literacy within academic institutions.

As both a teacher and a graduate student, I found myself banging my head against the same four brick walls of literacy understood as reading, writing, listening, and speaking. I felt confined by these walls and believed many students' abilities were being overlooked by assessments that never thought to ask about the knowledges and ways of making-meaning children were coming to school with. I could not help but wonder why the practices and protocols I witnessed within school systems were failing to address many children as complex, knowledgeable beings. Unfortunately, at the time I lacked the vocabulary and experience to clearly articulate and advocate for such learners, yet it continued to tug at me. Situating all children as competent meaning makers, both now and back then, seems to bump-up against conventional narratives of literacy that are limited to the reading and writing, and subsequently, listening and speaking (albeit viewing and representing have become part of the conversation). This constant tension begs the 
question of how definitions of literacy can account for multiple ways of being and knowing?

I began asking the aforementioned question in my third year of teaching. Subsequently, the question I asked of myself was how could I support students' classroom literacy achievement by leveraging competence and confidence? In my master's work, I turned to theories of multiliteracies (Cope \& Kalantzis, 2009; Courtland \& Gambell, 2010; New London Group, 1996) to bridge home and school literacies. Additionally, my hope was to achieve "success for all learners" (I will come back to this). I was happy to find Cope and Kalantzis (2009) who illuminated "literacy teaching is not about skills and competence; it is aimed at creating a kind of person, an active designer of meaning, with a sensibility open to differences, change and innovation" (p. 175). Multiliteracies, as espoused by the New London Group (1996), addresses a global societal shift and the rapid introduction of new technologies and means of communication. Significantly more complex than solely technologies, in many ways multiliteracies has changed how education and literacy are approached. Courtland and Gambell (2010) further suggest that multiliteracies are to include all forms of text and reflect the multiplicity of modes of communication. Multiliteracies theories aid my understanding of the creation and expression of meaning in all sign systems and connect literacies used in school with those used at home, as well as within other discourse communities. This shift in the definition of literacy affords students and teachers more opportunities to think, learn, and communicate in more ways than ever before.

\section{More than Multiliteracies}

Today, I shift my language and instead ask, how classroom practices and protocols might address children as being, or better yet, becoming? I understand and appreciate why I was originally drawn to multiliteracies as a means of addressing the complexities I was seeing in the classroom; but three years later, I am left unsatisfied and thirsty. Yes, the world we live in has changed, and it continues to do so. The ways we communicate have changed and will continue to change. Those realities make it easy to recognize the affordances of enabling children to make meaning with the multiplicity of resources available to them. But, I wonder if we now live in a post-multiliteracies world? If so, what do post-multiliteracy theories entail? Though I am not prepared to think with these ideas just yet, I have begun to consider how contemporary understandings of literacy must exist within a post-Truth and Reconciliation Commission ([TRC], 2015) world.

The Final Report of the TRC (2015) attributes generational miseducation for the "troubled relations" between Indigenous and non-Indigenous peoples. It states, "education must remedy the gaps in historical knowledge that perpetuate ignorance and racism" (p. 117 ) and "transform Canadian society so that our children and grandchildren can live together in dignity, peace, and prosperity on these lands we now share" (p. 4). The TRC brought an overdue awareness to Canadian society and awoke my understanding of colonial classrooms being places of curricular and pedagogical violence (Freire, 1985; Seidel, 2014; TRC, 2015). Again, I was faced with another need to renegotiate my articulation of literacy. When I set out to do good with my master's project, Success for all Learners, I did not stop to ask myself, "success defined by whom, and at what cost?". I thank my mentor, Cree/Métis scholar, Dr. Trudy Cardinal for helping me think with that jagged question. I can still feel the sting of her asking me the question the first time I sat 
in her office and opened up about who I am and the dreams I had for education. It still chokes me up to think about the notion of potential pain I have inflicted upon students because I failed to understand colonial violence and the ways we continue to assimilate students in our schools through the use of one-dimensional assessments and narrow understandings of literacy competence. It was in the brilliant red of Trudy's sixth floor office that I knew I had to continue negotiating literacy. Symbolizing both the passion and the urgency, the red still speaks to me as if to say, "the time is now". Because I no longer see it as possible to neglect students as four-part persons, we must create a counterideology for our youth, and for ourselves. How might we broaden understandings of literacy to encompass and embrace a whole person, as they are, have been, and continue to become, within a network far bigger than just themselves?

\section{Literacy as Life Lived}

I come from a family of driven, creative, vivacious women. My great-

grandmother shared a house with her aunt and her sister and their spouses and children in downtown Montreal. The five children often hosted friends and neighbourhood children. At night, their Great Auntie Ver would tell stories of Ireland, and tales of fairies, pixies, and leprechauns. These stories, I've been told, would fill the room with wonder and awe as the children would listen with great anticipation and buzz with excitement when hustled off to bed. My maternal grandmother was one of those five children. She too was a storyteller with a gift. She could spin a tale that would captivate my whole being, with no rehearsal necessary. My grandmother created a whole world with characters that lived on in her stories for years, even publishing them for us to enjoy forever in written word. A gift to be cherished and shared time and time again even though she has since passed.

- Honouring Indigenous, Personal, and Relational Knowledge in Literacy Learning (graduate course), Final Reflection; December 2018

In framing my experiences through this broad lens of literacy, I recognized the need to turn to Indigenous knowledges and scholarship to best make sense of and articulate my thinking. I have hoped to show through my writing how my understandings of literacy have shifted overtime. What I have not yet been able to show is how long I grappled with articulating my (dare I say current) belief that literacy is life encompassing. I spent countless hours reading and rereading, as graduate students do. I sent frantic emails and sat down with many mentors in hopes of finding a well-articulated literacy theory that described what I have been trying to say, but nothing quite fit. Until recently, that is. It was in a conversation with my colleague, Yina Liu, that an elevated conceptual understanding finally dawned on me. Full of sheer frustration and bruised by defeat, I was trying to explain that even within the work of Indigenous literacy scholars I had been reading, what I was trying to say was seldom laid out in the literature and discussed, despite my ability to see it clearly between the lines. It was as if it was accepted as fact... and then it clicked. With excitement I blurted out "it's a worldview"!

In order for me to best negotiate literacy as I currently do, I had to understand this is not stemming from one particular literacy theory, but from an understanding of the sacred nature of literacy learning within Indigenous paradigms. Blackfoot scholar, Suzanne McLeod (2016), of Siksika Nation writes: 
literacy as defined from an Indigenous lens is one of a collective and holistic lifelong journey, stemming from the belief that it includes all ages, beginning in the womb and even before. Traditional knowledge also tells us that learning continues after the spirit finishes its time on earth and returns to the spirit world; it is intergenerational in that all generations are constantly learning in their interactions with each other. (p. 2)

Oneida scholar, Eileen Antone (2003), from Onyota'a:ka, echoes this sentiment by stressing, "the importance of literacy as expressed from an Aboriginal perspective is a way of life based on a wholistic world view" ( p. 8). Antone and McLeod both express that literacy within an Indigenous worldview pertains to intimate spiritual, emotional, mental, and physical aspects for individuals and communities. According to a Treaty 7 and urban Elders consultation, which McLeod writes about, "Indigenous literacy is 'a lifelong process; it is simply not book learning. Indigenous literacy is being able to walk comfortable within the mainstream world and the Indigenous world."' (p. 11).

As a non-Indigenous woman, I do not walk in two worlds, rather I find myself in an in-between where my commitment to allyship is bridged by my ability to listen and learn with all four-parts of my person. It is important to again acknowledge the lineage of this knowledge which has been embedded within languages, the Land, and oral teachings for thousands of generations. Grounded in this humble understanding, my offering of "literacy as life lived" is not a new thought, nor is it mine to claim. It has however, enabled me to think (for now) about where I situate myself as an emergent literacy scholar.

I believe there is no separating an individual from their world. My way of coming to this knowing was relational and based on my lived experiences with children and families within and beyond institutional landscapes. Even in my own negotiations of literacy, I always come back to the world I know. As such, I believe there is no separating one's lived experience from what constitutes literacy. This belief speaks to why I am so drawn to narrative inquiry which reiterates how both life and research are composed "in the midst of uncertainty... [of] people, places, and things as becoming" (Clandinin \& Connelly, 2000, pp. 144-145).

\section{Part Two}

The Uncertainty of Becoming

Our minds are constantly being shaped and manipulated, but our hearts hold who we are. How often do I lead with my head rather than my heart? How often do I rush? Do I over analyze and harbour feelings of resentment and shame when I struggle? All too often! Maybe it is important to allow ourselves some grace. Is it possible to be comfortable in our own discomfort? Is there space to learn from the silences?

- Honouring Indigenous, Personal, and Relational Knowledge in Literacy Learning (graduate course), Online Reflection; September 2018

Embracing an understanding of literacy as life lived, I began to wonder with the sentiments of Paulo Freire (1985). How have I learned to navigate uncertainties? And what literacy skills are necessary to "create a spirit in which we are certain by not being certain of our certainties" (p. 17)? In rereading my writing from my first year of doctoral studies, 
I noticed a sadness in my writing and associated this with the tensions I had experienced with school systems. Before returning to university for my doctoral program, I had seriously questioned my position as a teacher once I awakened to the ways colonialism negatively shaped our classrooms, expectations, and practices. Much of my writing expressed overwhelming frustration and a sense of helplessness. But among these frustrations I noticed I was consistently writing about how I was living within these dominant narratives. I noted when I pushed back, or wished I had. I wrote about sometimes feeling defeated and voiceless. What echoed throughout my writing over the course of a year, was an understanding of slowing down, a recognition of my own vulnerability, the desire to walk in good ways, and emerging understandings of story as research. These threads will be further examined below and offer a way to think about my own experiences of becoming more comfortable with uncertainty.

The following threads are part of illustrating my understanding of lived experiences in education and research. This next section offers a glimpse into the ways I created counter-ideologies that served me as I negotiated uncertainties of the institution and my own ways of being. Shaped by the words of the late Anishinaabe scholar, Dr. Mary Young (2005), "stories are living things ... a story is not something you figure out the meaning of but something you carry with you the rest of your life to talk back and forth with" (p. 143). This, for me, is the beginning of what I hope is a beautiful conversation.

\section{Moving Mountains}

\section{For once in your life, for once lay your ambitions aside; And instead of moving} mountains, let the mountains move you.

- Skylar Grey

I remember exactly where I was when I first heard these lyrics in Skylar Grey's (2016) song, "Moving Mountains". While snow fell softly outside in the majestic Rocky Mountains of Banff National Park, I tucked myself away inside the chalet to focus on my writing. I chuckled at the lyrics and joked to myself that I would make that a priority once my master's was completed; come the spring, when I would have the time to let the mountains move me. The song's lyrics painted a picture of a me that strived to prove her worth, a me that had goals and dreams, and attaining them took precedence over taking the time to embrace the journey. Although this memory saddens me now, it continues to guide me in my journey of becoming a researcher.

I recalled these lyrics in early December of 2018. My first term as a PhD student was coming to an end and I had an increasing awareness that I was doing it again: I would make time to let the mountains move me once the term was done; once my papers were done; once I had a hold on this new journey. I did not recognize at first how much I was isolating, and honestly losing myself, in "academic mode". Again, my ambitions preceded my desire to embrace the process, to live and learn humbly.

Full stop.

Something must change.

I allowed my awareness to take precedent and chose to take time to live in the moment. Being away from home, my mountains were not an option. Instead, I drove out to a friend's acreage and gave myself permission to spend the evening enjoying myself 
alongside friends who are family, in front of a warm fire, under a million stars. Stepping back was what it took for me to begin examining the discomfort I was feeling.

A younger me believed in "fake it "til you make it". A mantra that led to my master's journey being filled with tension. Friends, family, and colleagues praised my efforts and accomplishments, while I stressed about being an imposter, bound to be caught. Though I loved the learning experiences, I felt far from being a "master of education". This feeling, of being out of place, was only amplified when I started my doctoral program. I noted how much control I felt I needed in any given moment, and while my energy was diverted in keeping up the façade of "becoming the expert", I cried as I battled feelings of inauthenticity and shame.

This first year of doctoral coursework has truly called me to think, but not in the ways I was used to within academic institutions. I have not found answers this year as I immersed myself in learning through Indigenous relational ways of being and knowing and autobiographical narrative inquiry. No, instead, I have been begged to slow down. Begged to create space for reflection. Begged to inhale fully before considering the need to exhale (F. Elliott, personal communication, January 19, 2019). Creating that space has not come easy, but it has come with a need to embrace vulnerability as I venture further with uncertainty.

\section{Embracing Vulnerability}

Recently, I was thanked for my vulnerability in sharing my stories. I embraced this as the deepest compliment, yet when articulating his gratitude, the gentleman expressed his reservation to use the word "vulnerable" because of its negative connotations in our society. Little did he know how much I had grappled with how to offer my story in a good way. Little did he know that there was no other option than for me to be vulnerable. And it terrified me!

- Personal Journal Reflection; January 2019

I often find myself wrestling with notions of head knowledge and heart knowledge when writing for academic purposes. I distinctly remember being unsure and uncomfortable in my masters' research with articulating my knowledge in scholarly ways without losing the heart in my voice. I woefully recognize how I failed to understand that the two are not mutually exclusive, nor does one have to be seen as greater or lesser than the other in academic spaces. Brené Brown (2010) offers me a way to think deeper about the role of heart knowledge in research through her use of the word and concept of courage. From the Latin word cor, meaning heart, the original definition was to tell the story of who you are with your whole heart. Considering my positionality as a novice researcher, I wondered how I could demonstrate such courage in a calculated way, a way that would not leave me feeling naked. Could I master being vulnerable without having to feel exposed and unsure? Brown's (2012) definition of vulnerability as "uncertainty, risk, and emotional exposure" (p. 2) made me think, perhaps not.

I have known uncertainty intimately throughout this first year of my doctoral program, but I was terrified of letting it show. What would people think? It surprised me to learn that the shame and inferiority I carried so closely was described, in great detail in Brown's (2012) research. She uses the term scarcity to speak to those feelings of "never enough" (p. 25). For me, that manifested as not smart enough, not articulate enough, not efficient enough. Only now can I see that each of these worries amounted to my fear 
of being vulnerable. It is not accurate to say that I am afraid that I am not enough, rather I am frightened of how I will be perceived by others if I reveal my authentic, imperfect self. Worse, is the deep fear of revealing completely and being judged negatively. And yet, I know I must show up wholeheartedly in order to do justice to my research and myself.

Wholeheartedness is described as being enough, and "a way of engaging with the world from a place of worthiness" (Brown, 2012, p. 9). Brown (2012) describes the journey to wholeheartedness as encompassing courage, compassion, and connection; and an understanding that our humanly imperfections make us who we are. On a landscape where I had always felt I needed to be perfect, I began to recognize, by embracing my own imperfections, and I began to reclaim my self-acceptance. I started to let people in and admit how scared I was to not have all the answers. Acknowledging these fears and perceived inequities aloud pressed the boundaries of my comfort zone, but also came with an overwhelming and humbling realization that I am upon these academic landscapes to learn, not to exhibit that I have all the answers. This revelation enabled me to lower the façade I had tried so hard to hide behind and I began to better honour myself and others with my whole heart. My developing understanding of vulnerability and courage was further nurtured through exploring the ways I am being called to walk in good ways as a researcher.

\section{Walking in Good Ways}

And if you want I could tell the truth, that this life takes a toll on you; I spend nights stitching up the loose threads of my soul and in the morning I'm bullet proof, in the morning I'm bullet proof. So, keep your time, keep your mind, keep it humble; start your life in the middle of the jungle, you, young blood. Rub your eyes, be surprised, keep hungry; stay alive, try to lose all of your money, you, young blood.

- Noah Kahan

I believe there are hard things to deal with upon this academic landscape. I still am not fully at peace with how 'who I am as a woman' and 'who I am becoming as a researcher' can be congruent in institutional spaces. I recognize, at times, dominant narratives (present or perceived) of polished perfectionism leave me "stitching up the loose threads of my soul" so that I too can be bulletproof. But I also recognize that to approach my research wholeheartedly, I need to conduct myself authentically and artistically through intentional vulnerability. As such, I began to wonder what it would mean for me to walk in good ways with my heart within institutional spaces, and if I would be able to get there.

During the Winter Term, I engaged in a course, Assessment as Pimosayta Honouring Children: Indigenous and Relational Approaches taught collaboratively by Drs. Janice Huber and Trudy Cardinal. This course invited me to think alongside the Anishinaabe concept pimosayta, meaning to walk together in good ways. It was timely and incredibly appropriate, coming during a period of struggling to connect to graduate studies in genuine ways, that I would be invited to think alongside my experiences, and those of others, to see lived stories as sources of true and worthy knowledge. It was significant to me that I never asked to legitimize my lived experiences, nor were they ever a source of prominence.

Instructors and students gathered each Wednesday evening in a unique setting of both undergraduate and graduate students. I felt my unease at the beginning, buying into 
the dominant narrative that there was a distinct difference between the two groups, yet, I was surprised there was no distinction in the structure of the course. Despite some apprehension, I allowed myself to trust in the process. I am glad I did. The space we cocreated was not based on academic hierarchy. Instead, we offered each other a place to come fully as all that we were. We imagined possibilities for ourselves and for education beyond what many of us could have imagined, having been shaped and structured within colonial spaces for much of our lives. I can see the impact this learning experience has had on my ability to reimagine what it means to be an academic in rereading my final course reflection.

A final paper comprised of poetry and prose. I'm not sure I could have imagined that I would be afforded the opportunity to be true to the woman I am and, in such, find myself. Shawn Wilson counters "if I hadn't seen it with my own eyes, I wouldn't have believed it", with "if I hadn't believed it, I wouldn't have seen it". Thank you for believing it, because if not for your vision, I wouldn't have experienced it, and if I hadn't have felt it, I wouldn't have known it existed.

In circle we sit, hearts beating minds afire. I am not the same woman I was in January. I have grown completely as a four-part person heart, body, mind, and spirit. Encouraged by the invitation and space to show up as I am. As I am a woman, as I am as a daughter, as a granddaughter, a partner, a mom, a friend, an educator, a researcher. May I remember to never leave that at the door, and to extend the same invitation to those around me.

Walking alongside wonders, tensions, lingerings, and stories has given me hope for the future of education. This room is full of beautiful people who have been willing to share who they are - in the words of Manu Meyer, "the light in me sees the light in you". I am filled with so much love. So much vulnerability. A quality I was scared to possess before now. Terrified of showing I may not know it all. Fake it until you make it - the way I've always known. But humility has begun to heal me. And vulnerability has opened my heart and my soul to a world of learning. This journey through story has strengthened my intimate relationship with myself. Though I still have a long way to go, I am appreciative of the times I've had through this class to listen to and sit with my own stories - who am I and what do I have to offer.

- Assessment as Pimosayta - Honouring Children: Indigenous and Relational Approaches (graduate course), Final Reflection; April 2019

\section{Current Conclusions}

My advice to myself? Cherish the learning, the stories. If they change you, let them. Tell and retell your stories. Maybe to others, but for sure to yourself. Honour the stories of those around you, the ones that are shared, and the ones that are not. Everyone has their own warrior story that holds their identity, and intricately weaves together who they are and who they are becoming.

- Honouring Indigenous, Personal, and Relational Knowledge in Literacy Learning

(graduate course), Final Reflection; December 2018

The time I have spent examining my lived experiences has led me to explore and reflect upon the ways I have conceptualized literacy across time and landscapes. Delving into this research has given me a glimpse into the complexities of my ever-evolving identity within literacy scholarship. I am able to see now how each lens has the potential 
to shape literacy teaching and learning. I am thankful for the opportunity this has given me to think alongside the theories that previously served me, to my current postulation of literacy as life lived. I have awakened to how my experiences of becoming have been shaped within dominant narratives. Thinking with the threads of slowing down, being vulnerable, and walking in good ways, I am curious to further explore whether these concepts resonate with my understandings of literacy as life lived.

I have come to embrace uncertainties throughout my journey. I continue to linger with the roles story and vulnerability have in my understanding of becoming. In writing this paper, I have been called to travel in and out, back and forth, not only through the literature, but through my own understanding of, and connection to, the concepts. As I conclude, I am awake to the ways even this paper is shaping the researcher I am becoming. I find myself more intrigued by my current understanding of literacy as life lived and I am excited at the prospects of delving in and experiencing the many affordances and tensions that will ensue. My current understanding of narrative inquiry encourages me to embrace this learning process. I must continue to lean into the tensions and uncertainties in order to grow from them. For so long I have longed to be where I am, and am humbly reminded to relish in the becoming.

I feel myself drawn to the blades of tall grass. Once green, now coloured from the winter cold and wind. Not knowing fully why I am drawn here, I bend down to offer tobacco and my prayers. I am thankful for the faint warmth of sun on my back, for the brisk air nipping at my cheeks, for this opportunity to learn with the Land. Open to guidance, to strength, and to vision.

I put my hand to the earth with my offering and ask for three blades of grass. My motions are not quite voluntary, but rather I trust what I feel I must do. I attempt to braid the blades of grass as I walk back toward the building. Nä̈vely, I rack my brain to learn the lesson this experience has taught me. Why was I drawn to the grass? As I ponder this, expecting answers to come rapidly, I absent-mindedly start to braid the grass into a ring; only to have to put it aside once I am inside.

Though I return to my grass ring a mere hour later, the grass has dried, and it is brittle. The blades fracture between my fingers and completing the ring seems nearly impossible. I tie it into a knot and place it into my coat. My disappointment and defeat dissipate as I zip the ring safely in my pocket.

It is in a sharing circle the following week that the teaching becomes clear to me. The grass I was so drawn to was hearty and strong. I recall watching it blow in the wind and thinking how resilient it was. It had been thriving, but only while it was grounded. Once it was uprooted, it became fragile and unpredictable. The lesson is simple: I too am strong and resilient when I ground myself through authenticity, when I stay rooted in each moment. Though my ambitions call to me, they must not precede my desire to embrace the process, to live. Yes, remember to stay grounded, and let the mountains move you.

\section{References}

Antone, Eileen. (2003). Culturally Framing Aboriginal Literacy and Learning. Canadian Journal of Native Education, 27(1), 7-15.

Battiste, M., \& Henderson, J. (2000). The importance of language for Indigenous 
knowledge. In M. Battiste \& J. Henderson (Eds.), Protecting Indigenous

knowledge and heritage: A global challenge (pp. 73-85). Vancouver, BC: Purich

Publishing.

Brant Castellano, M. (2000). Updating Anishinaabe traditions of knowledge. In G. J. S.

Dei (Ed.), Indigenous knowledges in global contexts: Multiple readings of our world (pp. 21-36). Toronto, ON: University of Toronto Press.

Brown, B. (2010). The power of vulnerability [Video file]. Retrieved from https://www.ted.com/talks/brene_brown the_power_of_vulnerability?language=e $\underline{\mathrm{n}}$

Brown, B. (2012). Daring greatly: How the courage to be vulnerable transforms the way we live, love, parent, and lead. New York, NY: Gotham Books.

Bogdan, R. C., \& Biklin, S. K. (2003). Qualitative research in education: An introduction in theory and methods (4th ed.). Boston, MA: Allyn \& Bacon.

Boler, M. (2004). Teaching for hope: The ethics of shattering world views. In D. P.

Liston \& J. W. Garrison (Eds.), Teaching, learning, and loving: Reclaiming passion in educational practice (pp. 114-129). Oxford, UK: RoutledgeFalmer.

Cardinal, T. (2010). For all my relations an autobiographical narrative inquiry into the lived experiences of one Aboriginal graduate student. (Unpublished Thesis). University of Alberta, Edmonton, AB, Canada.

Clandinin, J., \& Connelly, M. (2000). Narrative inquiry: Experience and story in qualitative research. San Francisco, CA: Jossey-Bass.

Cope, B., \& Kalantzis, M. (2009). "Multiliteracies": New literacies, new learning. Pedagogies: An International Journal, 4(3), 164-195.

Courtland, M. C., \& Gambell, T. (2010). Literature, media \& multiliteracies in adolescent language arts. Vancouver, BC: Pacific Educational Press.

Dewey, J. (1916). Democracy and education. New York, NY: Gutenberg. Retrieved from https://www.gutenberg.org/files/852/852-h/852-h.htm\#link2HCH0011

Dewey, J. (1938). Experience and education. New York, NY: Macmillan.

Freire, P. (1985). Reading the World and Reading the Word: An Interview with Paulo Freire. Language Arts, 62(1), 15-21.

Friesen, J. W., \& Snow, J. D. (2016). Missing the mark in cross-cultural communication: A case study of a Stoney Nakoda Sioux community. Alberta Voices, 13(1), 1926.

Greene, M. (1995). Releasing the imagination: Essays on education, the arts, and social change. San Francisco, CA: Jossey-Bass.

Grey, S. (2016). Moving mountains. On Natural causes [Spotify]. Interscope Records.

Kahan, K. (2017). Young blood. On Busyhead [Spotify]. Republic Records.

Latremouille, J. M., Bell, A., Kasamali, Z., Krahn, M., Tait, L., \& Donald, D. (2016). kistikwânihk êsko kitêhk: Storying holistic understandings in education. Journal of the Canadian Association for Curriculum Studies, 14(1), 8-22.

Martin, K. L. (2003). Ways of knowing, ways of being, and ways of doing: A theoretical framework and methods for Indigenous re-search and Indigenist research. Journal of Australian Studies, 27(76), 203-214.

McLeod, S. (2016). Indigenous Literacy: Literacy \& Foundational Learning for Indigenous Adults (Investment Strategy \& Framework to Guide Calgary Learns). Métis Calgary Family Services Society. Retrieved from 
https://www.calgarylearns.com/wp-content/uploads/Foundational-Document-andInvestment-Guide-Final.pdf

New London Group. (1996). A pedagogy of multiliteracies: Designing social futures. Harvard Educational Review, 66(1), 60-93.

Patton, M. A. (2002). Qualitative research and evaluation and research methods ( $3^{\text {rd }}$ ed.). Thousand Oaks, CA: Sage.

Truth and Reconciliation Commission of Canada. (2015). Canada's residential schools: Reconciliation (Vol. 6). Retrieved from http://caid.ca/TRCFinVol62015.pdf

Young, M. I. (2005). Pimatisiwin: Walking in a good way. Winnipeg, MB: Pemmican Publications.

\section{Author Biography}

Darcy Courtland is a second-year doctoral student in the department of Elementary Education at the University of Alberta. Darcy's passion for language and literacy, social studies education, and personalized learning were brought to life in the elementary classroom for seven years. She received her BEd from the University of Alberta, and a MEd from the University of Victoria in Leadership in Language and Literacy. Darcy's current research interests are in the areas of vulnerability and story in research as well as education for reconciliation. Her proposed doctoral research seeks to better understand the personal and professional learning journeys of non-Indigenous teachers as they make their commitment to reconciliation. 